\title{
PENGUATAN KARAKTER PADA REMAJA BERHADAPAN DENGAN HUKUM DI LEMBAGA PEMBINAAN KHUSUS ANAK (LPKA)
}

\author{
Mutiara Ayu Lestari ${ }^{1}$, Meilanny Budiarti Santoso² \\ 1,2 Ilmu Kesejahteraan Sosial, Fakultas Ilmu Sosial dan Ilmu Politik, \\ Universitas Padjadjaran \\ 1'mutiaraayulestari36@gmail.com, 2meilannybudiarti13@gmail.com
}

\begin{abstract}
ABSTRAK
Setiap individu pasti melewati masa remaja sebagai salah satu periode perkembangan menuju masa dewasa. Masa remaja disebut sebagai masa usia bermasalah. Tidak jarang seorang remaja terjebak dalam permasalahan yang menyebabkan mereka melakukan tindak pidana sehingga harus menjalani proses pembinaan di Lembaga Pembinaan Khusus Anak (LPKA) sebagai bentuk masa penahanan. Salah satu faktor penyebab kenakalan remaja adalah tidak diberikannya pemahaman tentang perilaku asertif pada diri remaja. Asertif sendiri dapat diartikan sebagai ekspresi dari perasaan dan belajar untuk bertindak atas dasar perasaan, keinginan dan kebutuhan namun tetap menghormati hak-hak orang lain. Penguatan karakter dapat menjadi solusi untuk mengurangi tindak kenakalan pada diri remaja. Teknik Assertiveness Training menjadi metode intervensi yang dipilih sebagai upaya penguatan karakter dalam usaha pembinaan kepada anak didik LPKA yang sulit untuk mengekspresikan perasaannya seperti sulit mengatakan "tidak" kepada orang lain. Penggunaan model intervensi ini dirasa tepat dengan harapan ketika proses intervensi selesai maka para anak didik dapat menentukan tindakan yang tepat dan mampu mengekspresikan diri namun tetap menghargai perasaan dan hak orang lain.
\end{abstract}

Kata Kunci: Assertiveness Training, Karakter, LPKA, Remaja, Remaja Berhadapan dengan Hukum

\begin{abstract}
Each individual must pass adolescence as one of the periods of development towards adulthood. Adolescence is called as a troubled age. It is not uncommon for a teenager to get caught up in a problem that causes them to commit a crime so they have to undergo a coaching process at the Children's Special Development Institute (LPKA) as a form of detention. One of the factors causing juvenile delinquency is not given an understanding of assertive behavior in adolescents. Assertive itself can be interpreted as an expression of feelings and learning to act on the basic of feelings, desires and needs but still respect the rights of others. Strengthening character can be a solution to reduce misbehavior in adolescents. The Assertiveness Training technique is an intervention method that is chosen as an effort to strengthen character in an effort to guide LPKA students who are difficult to express their feelings such as difficult to say "no" to others. The use of this intervention mothod is felt right in the hope that when the intervention process is complete, the students of LPKA can determine the right action and be able to express themselves but still respect the feelings and rights of others.
\end{abstract}

Keywords: Assertiveness Training, Character, LPKA, Adolescence, Adolescence with Law

\section{PENDAHULUAN}

Masa remaja merupakan periode penting dalam rentang perkembangan seorang individu. Masa remaja disebut sebagai suatu periode transisional, masa perubahan, masa usia bermasalah, masa individu mencari identitas diri, usia menyeramkan (dreaded), masa unrealism dan ambang menuju kedewasaan. (Krori, 2011). Kata "remaja" (adolescence dalam Bahasa Inggris) sebenarnya berasal dari Bahasa Latin yaitu Adolescere yang berarti tumbuh atau tumbuh untuk mencapai kematangan. Istilah kematangan yang dimasksud meliputi kematangan fisik ataupun kematangan sosial serta psikologis.

Pada tahun 1974, WHO (World Health Organization) mendefinisikan remaja secara konseptual yang meliputi kriteria biologis, 


\begin{tabular}{|c|c|c|c|c|}
\hline $\begin{array}{c}\text { Prosiding Penelitian \& } \\
\begin{array}{c}\text { Pengabdian Kepada } \\
\text { Masyarakat }\end{array}\end{array}$ & $\begin{array}{c}\text { e ISSN : 2581-1126 } \\
\text { p ISSN : 2442-448X }\end{array}$ & Vol 6, No: 3 & Hal: 297 - 306 & Desember 2019 \\
\hline
\end{tabular}

psikologis dan sosial ekonomi. Definisi tersebut menyatakan bahwa remaja adalah suatu masa di mana (Sarwono, 2011):

1. Individu berkembang dari saat pertama kali ia menunjukan tanda-tnada seksual sekundernya sampai saat ia mencapai kematangan seksual (kriteria biologis).

2. Individu mengalami perkembangan psikologis dan pola identifikasi dari kanakkanak menjadi dewasa (kriteria sosialpsikologis).

3. Terjadi peralihan dari ketergantungan sosial-ekonomi yang penuh kepada keadaan yang relatif lebih mandiri (kriteria sosial-ekonomi).

Seorang remaja tidak lagi termasuk ke dalam golongan anak-anak, namun juga belum termasuk ke dalam golongan orang dewasa. Oleh karena itu, masa remaja disebut sebagai masa peralihan dan sering dikenal sebagai masa pencaharian jati diri. Hurlock (1981) menyebutkan bahwa remaja adalah mereka yang berada pada rentang usia 12-18 tahun. Hurlock (1990) juga membagi masa remaja menjadi dua masa yaitu masa remaja awal (11/12-16/17) dan masa remaja akhir (16/17 - 18 tahun).

Monks (dalam Yusuf, 2005) membagi masa remaja menjadi 3 masa kelompok usia yaitu sebagai berikut:

1. Remaja awal yang berada pada rentang usia 12-15 tahun. Masa ini disebut masa negatif. Individu merasa bingung, cemas, takut dan gelisah.

2. Remaja pertengahan yang berada pada rentang usia 15-18 tahun. Pada masa ini individu menginginkan sesuatu dan mencari-cari sesuatu. Pada masa ini remaja memikirkan konsep diri dan konsep dirinya relatif stabil.

3. Remaja akhir yang berada pada sekitar usia 18-21 tahun. Pada masa ini individu mulai merasa stabil. Mulai mengenal dirinya dan mulai memahami arah hidup dan menyadari tujuan hidupnya.

Stanley Hall (dalam Santrock, 2003) menyatakan bahwa rentang usia pada masa remaja adalah 12-23 tahun. Dari beberapa pendapat di atas dapat disimpulkan bahwa batasan rentang usia pada masa remaja menurut para ahli sangat bervariasi namun pada umumnya dimulai pada usia yang sama.

Pada masa ini, terjadi perubahanperubahan pada diri remaja baik secara fisik ataupun psikologis. Perubahan itu dipengaruhi oleh faktor internal dan faktor eksternal dari diri remaja.
Faktor internal yang dimaksud yaitu berasal dari dalam diri remaja itu sendiri. Diantaranya seperti terjadinya perubahan bentuk fisik, psikis dan emosi. Sedangkan faktor eksternal yang dimaksud yaitu faktor-faktor di luar diri individu tersebut seperti keluarga, pertemanan, teman sebaya serta lingkungan masyarakat (Santoso, 2017)

Pada masa ini, remaja sering terlibat dalam tindakan berisiko yang lebih sering disebut dengan kenakalan remaja. Tindakan tersebut seperti perilaku melanggar status (membolos sekolah), membahayakan diri sendiri (menggunakan narkotika, berkendara dengan kecepatan tinggi), menimbulkan korban materi terhadap orang lain (perilaku yang menyebabkan kerugian pada orang lain seperti mencuri, merampas) dan perilaku menimbulkan korban fisik (perkelahian) (Jansen dalam Sarwono, 2001).Kata "Lapas Anak" pada saat ini sudah berubah menjadi Lembaga Pembinaan Khusus Anak (LPKA). Hal ini dilakukan sebagai bentuk nyata penghargaan dan perlindungan dari negara terhadap hak anak. LPKA juga menghapuskan pandangan mengenai lembaga pemasyarakatan yang identik dengan jeruji besi. Anak yang berhadapan dengan hukum (ABH) yang berada di LPKA disebut ANDIK atau anak didik. Selama berada di LPKA para ANDIK diwajibkan untuk mengikuti program pembinaaan yang diselenggarakan oleh LPKA.

Salah satu bentuk pembinaan yang dilakukan di LPKA adalah pembinaan karakter. Muchlas Samani (2011) berpendapat bahwa karakter memiliki arti sebagai nilai dasar yang membangun pribadi seseorang, terbentuk baik karena pengaruh hereditas maupun pengaruh lingkungan, yang membedakannya dengan orang lain, serta diwujudkan dalam sikap dan perilakunya dalam kehidupan sehari-hari. Dalam pendapat Lickona (2012) mengenai komponen karakter yang baik (components of good character) dikemukankan bahwa salah satunya adalah kebiasaan. Berdasarkan hasil assessment yang dilakukan di LPKA Kota Bandung, Para ABH mengatakan bahwa mereka sulit untuk mengatakan "tidak" dan tidak dapat mengekspresikan perasaannya dengan baik. Sering kali remaja terlibat dalam tindak kenalakan remaja contohnya tawuran karena kelompok menunjung tinggi rasa solidaritas di antara mereka, sehingga setiap anggota kelompok harus mengikutinya dan membuat individu lain dalam kelompok tidak dapat menolak ataupun menyampaikan pendapat pribadinya ketika mereka berada dalam kelompok (menjadi non-assertive). Adanya kebiasaan bersikap tidak asertif pada diri remaja cenderung dapat menimbulkan dampak 


\begin{tabular}{|c|c|c|c|c|}
\hline $\begin{array}{c}\text { Prosiding Penelitian \& } \\
\begin{array}{c}\text { Pengabdian Kepada } \\
\text { Masyarakat }\end{array}\end{array}$ & $\begin{array}{c}\text { e ISSN : 2581-1126 } \\
\text { p ISSN : 2442-448X }\end{array}$ & Vol 6, No: 3 & Hal: 297 - 306 & Desember 2019 \\
\hline
\end{tabular}

negatif salah satunya mengarah pada status remaja menjadi Anak Berhadapan dengan Hukum $(\mathrm{ABH})$. Salah satu menanamkan perilaku assertive adalah dengan memperkuat karakter remaja dengan metode intervensi assertiveness training.

Teknik assertiveness training dilakukan untuk menciptakan perubahan tingkah laku dan cara berpikir dari individu. Assertiveness training dilakukan dengan tujuan agar klien dapat berperilaku asertif. Tujuan dari assertiveness training adalah seperti yang dikemukakan oleh (Corey, 2009: 213) yaitu sebagai suatu teknik untuk membantu individu dalam melakukan hal-hal berikut ini, yaitu:

1. Tidak dapat mengungkapkan kemarahannya atau kejengkelannya

2. Mereka yang menunjukan kesopanan yang berlebih dan membiarkan orang lain mengambil keuntungan dari padanya

3. Mereka yang memiliki kesulitan untuk mengatakan "tidak"

4. Mereka yang mengalami kesulitan dalam menyatakan afeksi dan respon positif lainnya

5. Mereka yang merasakan tidak punya hak untuk menyatakan pendapat dan pemikirannya.

Jika seorang remaja dibiasakan untuk tidak menerapkan perilaku asertif, maka hal tersebut akan menjadi karakter pada dirinya. Perilaku asertif dapat diartikan sebagai ketegasan komunikasi dimana seseorang dapat mengekspresikan diri secara langsung dan jujur dalam situasi interpersonal namun tetap menghormati hak dan martabat orang lain. Ada tiga pengetahuan yang disampaikan dalam assertiveness training yaitu sikap non-assertive, assertive dan aggressive (Taftazani, 2019).

\section{METODE}

Penguraian pelaksnaan kegiatan ini dilakukan dengan metode deskriptif yang bertujuan untuk menjelaskan efektivitas penguatan karakter pada remaja yang berhadapan dengan hukum. Pelaksanaan kegiatan assertiveness training ini dilakukan di Lembaga Pembinaan Khusus Aanak (LPKA) kota Bandung yang berlokasi di Jalan Pacuan Kuda No. 3 Sukamiskin, Kecamatan Arcamanik, Kota Bandung, Jawa Barat. Proses pelaksanaan dilakukan kepada klien selama beberapa minggu.

Sumber data yang digunakan dalam mendukung kegiatan ini adalah sebagai berikut:
1. Data primer

Data primer merupakan data yang diperoleh secara langsung. Seperti data / informasi dari pihak Lembaga Pembinaan Khusus Anak (LPKA) kota Bandung, Hasil Assessment dengan klien dan para anak didik LPKA (ANDIK). Klien yang dimaksud merupakan seorang ANDIK remaja laki-laki berusia 17 tahun.

2. Data sekunder

Data sekunder merupakan data tambahan yang diperoleh dari referensi/dokumen yang terkait dengan isu dalam proses pendampingan, yaitu data / informasi dari yang bersumber dari jurnal, artikel, website, buku ataupun berita terkait dengan tema pendampingan.

Ada beberapa teknik pengumpulan data yang digunakan dalam proses pendampingan ini yaitu:

1. Wawancara Langsung

Wawancara langsung (tatap muka) dengan klien untuk memperoleh data / informasi mengenai keadaan atau kondisi yang dirasakan sebagai permasalahan oleh klien, sehingga harus ditangani. Proses wawancara menghasilkan genogram dan ekomap terkait keberadaan klien. Wawancara dilakukan sebanyak 1-2 kali dalam seminggu dengan durasi kurang lebih 1-2 jam / pertemuan.

2. Permainan (Games)

Dipilihnya teknik permainan (games) adalah sebagai upaya untuk menciptakan keakraban dengan para ANDIK, sehingga diharapkan dapat meningkatkan kualitas komunikasi dengan klien. Dengan melakukan permainan (games), diperoleh data / informasi tambahan dengan mengamati perilaku klien dan hubungan klien dengan ANDIK lainnya. Metode permainan juga dapat berbentuk bermain peran (role play) seperti dalam proses pengenalan assertiveness training kepada klien.

3. Studi Kepustakaan

Studi kepustakaan merupakan cara yang digunakan untuk memperoleh data / informasi dengan cara membaca berbagai literatur, buku ataupun dokumen yang sudah ada sebelumnya terkait dengan tema pendampingan.

Permasalahan klien adalah kesulitan untuk mengekspresikan perasaannya dengan baik, dalam rangka mengatasi permasalahan yang dihadapi 


\begin{tabular}{|c|c|c|c|c|}
\hline $\begin{array}{c}\text { Prosiding Penelitian \& } \\
\begin{array}{c}\text { Pengabdian Kepada } \\
\text { Masyarakat }\end{array}\end{array}$ & $\begin{array}{c}\text { e ISSN : 2581-1126 } \\
\text { p ISSN : 2442-448X }\end{array}$ & Vol 6, No: 3 & Hal: 297 - 306 & Desember 2019 \\
\hline
\end{tabular}

klien tersebut, metode intervensi yang dilakukan adalah assertiveness training. Selain di dasari oleh permasalahan yang sedang dihadapi klien, metode intervensi assertiveness training dipilih sebagai proses pembinaan karakter kepada klien dengan memberikan pemahaman bahwa segala tindakan yang dilakukan oleh individu pasti memiliki dampak.

Perilaku asertif sendiri dibagi menjadi lima aspek, yaitu: aspek ketegasan, tangggung jawab, percaya diri, kejujuran dan menghormati orang lain (Hartono dkk, 2013). Ada beberapa prinsip yang harus diterapkan dalam pelaksanaan assertiveness training yaitu keterampilan yang dilatih dan teknik yang digunakan (Geral Corel, Op, Cit, hal 220).

Keterampilan yang dilatihkan meliputi (Geral Corey, Op, Cit, Hal 220):

1. Melatih individu memahami perilaku asertif dan agresif

2. Membantu mengidentifikasi hak personal dan orang lain

3. Meningkatkan perilaku asertif melalui praktek langsung

4. Melatih kemampuan berkomunikasi secara langsung pada orang lain

5. Mengekspresikan sesuatu dengan baik

6. Menyampaikan perasaan dan pikiran

7. Mengekspresikan kemarahan

8. Mengatakan tidak untuk permintaan yang tidak sesuai

9. Menyampaikan kebutuhan dan keinginan

Teknik komunikasi yang dilatihkan yaitu sebagai berikut (Geral Corey, Op, Cit, Hal 220):

1. Menggunakan bahasa tubuh yang asertif yaitu kontak mata yang tepat, ekspresi wajah yang sesuai dengan pembicaraan, volume bicara sesuai, postur tubuh tegak dan relaks.

2. Menggunakan pernyataan "saya"' pernyataan ini berfokus pada problem bukan menyalahkan orang lain.

3. Penggunaan fakta bukan kesimpulan sepihak

4. Mengekspresikan pikiran, perasaan dan opini yang dimiliki

5. Membuat penjelasan

6. Berkata langsung dan meminta.

Menurut Redd dkk (1979), latihan asertif direkomendasikan untuk individu yang mengalami kecemasan secara interpersonal, tidak mampu menolak tindakan orang lain dan memiliki kesulitan berkomunikasi dengan orang lain. Dasar dari teori assertiveness training adalah pendapat bahwa banyak individu yang menderita karena tidak dapat mengungkapkan pendapatnya, membela hak atau kepentingan pribadinya, bersikap jujur dan terbuka tanpa merugikan orang lain (Musdariah, 2017).

Pelaksanaan teknik assertiveness training dapat dilakukan dengan cara mengkombinasikan beberapa metode. Dalam proses pendampingan ini, teknik assertiveness training dilakukan dengan menggunakan metode bermain peran (role play) dan metode kelompok (group work). Setelah dilakukan teknik role playing, berikutnya dilakukan teknik assertiveness training terhadap klien.

\section{HASIL DAN PEMBAHASAN}

Berdasarkan data Direktorat Jendral Pemasyarakatan tahun 2015, Provinsi Jawa Barat berada pada urutan ke dua sebagai provinsi dengan jumlah narapidana anak tertinggi di Indonesia yaitu sebanyak 194 anak. Lembaga Pembinaan Khusus Anak (LPKA) Kota Bandung, menjadi tempat pembinaan bagi anak-anak yang melakukan tindak pelanggaran hukum di provinsi Jawa Barat sejak tahun 2013. Menurut kepala subdirektorat pendidikan dan Pengentasan Anak (PPA) Kementerian Hukum dan HAM Gusti Ayu P. Swardani, menyatakan bahwa LPKA kota Bandung menjadi salah satu LPKA di Indonesia yang sudah memenuhi kelayakan standar.

Berdasarkan data Lembaga Pembinaan Khusus Anak Kota Bandung tanggal 02 Maret 2019, ada sebanyak 146 anak yang berada dalam masa bimbingan di LPKA Kota Bandung yang memiliki kapasitas sebanyak 408 orang. Berikut ini merupakan data yang diperoleh dari Jurnal Harian LPKA Maret 2019: 


\begin{tabular}{|c|c|c|c|c|}
\hline $\begin{array}{c}\text { Prosiding Penelitian \& } \\
\begin{array}{c}\text { Pengabdian Kepada } \\
\text { Masyarakat }\end{array}\end{array}$ & $\begin{array}{c}\text { e ISSN : 2581-1126 } \\
\text { p ISSN : 2442-448X }\end{array}$ & Vol 6, No: 3 & Hal: 297 - 306 & Desember 2019 \\
\hline
\end{tabular}

\section{Grafik 1}

Klasifikasi Usia Anak Didik (ANDIK) LPKA Kota Bandung

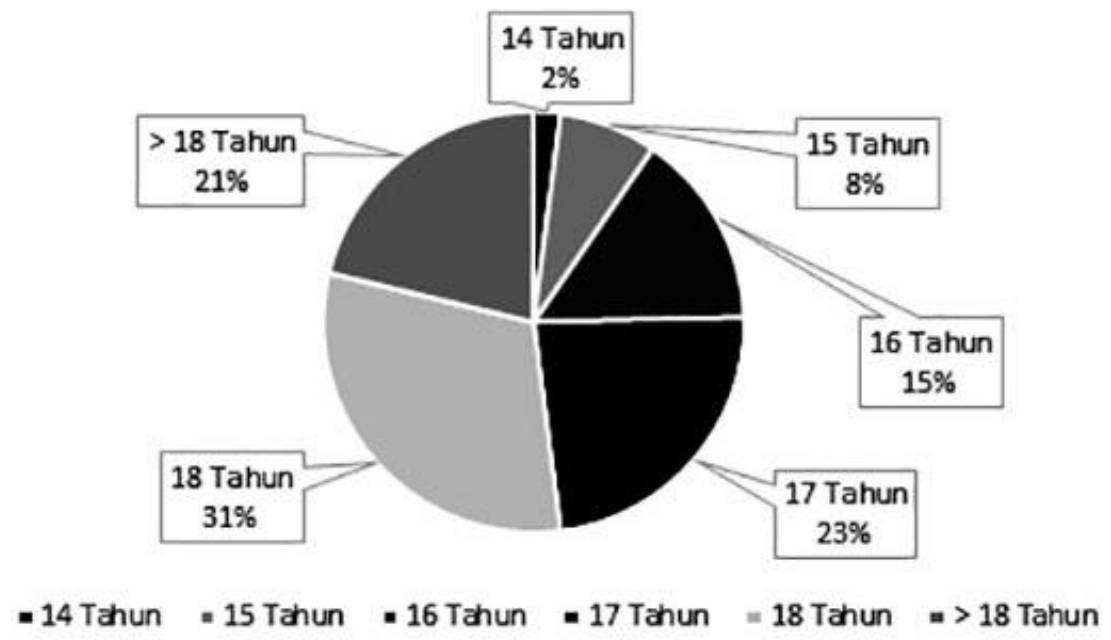

Sumber: Jurnal Harian LPKA Maret 2019

Berdasarkan data tersebut dapat dilihat bahwa semua ANDIK berjumlah 146 orang berada pada usia remaja dengan jumlah terbanyak berada pada usia 18 tahun yaitu sebesar $31 \%$.
Berdasarkan jenis tindak kejahatan yang dilakukan, yang terbanyak adalah kejahatan terhadap ketertiban yaitu sebanyak $36 \%$, yaitu tindakan yang mengganggu ketertiban umum seperti tindak tawuran.

Grafik 2

Klasifikasi Jenis Tindak Kejahatan

\begin{tabular}{|c|c|}
\hline $\begin{array}{l}\text { - pencurian } \\
\text { a kejahatan terhadap ketertiban } \\
\text { a penganiyayaan }\end{array}$ & $\begin{array}{l}\text { = pembunuhan } \\
\text { = perlindungan anak } \\
\text { a senjatatajam }\end{array}$ \\
\hline
\end{tabular}

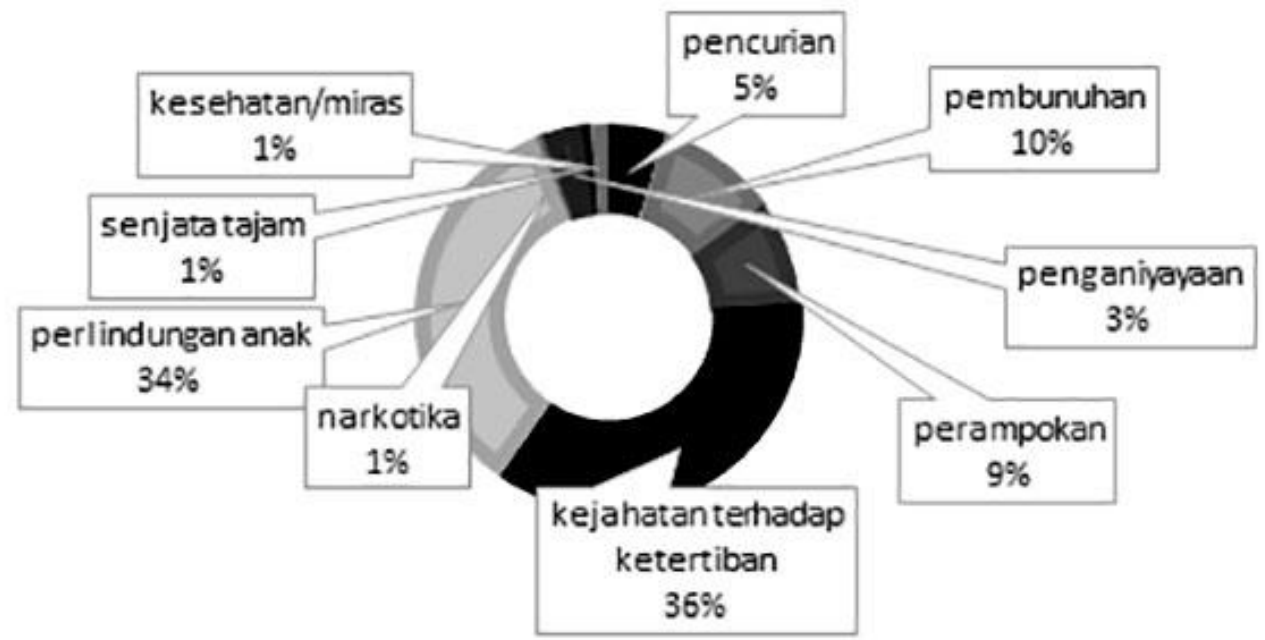

Sumber: Jurnal Harian LPKA Maret 2019 


\begin{tabular}{|c|c|c|c|c|}
\hline $\begin{array}{c}\text { Prosiding Penelitian \& } \\
\begin{array}{c}\text { Pengabdian Kepada } \\
\text { Masyarakat }\end{array}\end{array}$ & $\begin{array}{c}\text { e ISSN : 2581-1126 } \\
\text { p ISSN : 2442-448X }\end{array}$ & Vol 6, No: 3 & Hal: 297 - 306 & Desember 2019 \\
\hline
\end{tabular}

Dalam pelaksanaan kegiatan ini, klien adalah seorang remaja laki-laki berusia 17 tahun dengan jenis kejahatan yang dilakukannya adalah pelanggaran terhadap ketertiban. Dalam pelaksanaan proses intervensi yang dilakukan berdasarkan tahapan praktik pekerjaan sosial, ada beberapa tahapan yang harus dilalui sebelum menentukan treatment apa yang tepat untuk dilakukan bersama klien.

Sistematik (systematic practice) tahapan ini dibuat agar tidak terjadi ketidakjelasan arus / kebingungan dalam proses intervensi. Tahapantahapan tersebut terdiri dari assessment, plan of treatment dan evaluasi dan terminasi.

Tahapan pertama yang harus dilalui adalah assessment. Menurut Max Siporin (1975), assessment adalah proses dan hasil suatu pemahaman yang menjadi dasar bagi pelaksanaan kegiatan. Kegiatan assessment meliputi pengumpulan dan analisis data / informasi serta menggabungkan berbagai fakta yang telah ada, sehingga memberikan suatu pemahaman yang utuh. Assessment merupakan proses penting yang harus dilakukan dalam proses praktik pekerjaan sosial. Assessement merupakan proses yang holistik atau menyeluruh, sehingga proses assessment harus meliputi upaya-upaya yang melihat seluruh situasi yang dihadapi secara menyeluruh. Dalam melakukan assessment, data / informasi harus digali sebanyak-banyaknya, baik terkait klien ataupun lingkungan sosialnya dan bagaimana hubungan klien dengan lingkungan sekitarnya.

Pada tahap assessment, didapatkan data / informasi mengenai permasalahan yang hadapi klien, kekuatan serta kelemahan yang dimiliki klien serta apa yang menjadi kebutuhan klien.

Hal pertama yang dilakukan dalam proses pendampingan adalah pembuatan kontrak dengan klien untuk menentukan proses intervensi dan jangka waktu terkait lamanya intervensi yang akan dilakukan. Pada kontrak tersebut ditetapkan bahwa ANDIK yang bersangkutan bersedia untuk menjadi klien pada proses pendampingan.

Dalam proses ini didapatkan data bahwa klien merupakan remaja laki-laki berusia 17 tahun Pendidikan terakhir klien sebelum berada di LPKA Kota Bandung adalah pada bangku SMP. Klien sering berkumpul dengan teman-temannya yang dilakukan pada malam ataupun siang hari. Lingkungan pertemanan atau peer group tersebut sangat berpengaruh terhadap kehidupan klien sebelum masuk ke LPKA.

Dari cerita klien di dapatkan informasi bahwa klien merupakan seseorang yang mudah emosi dan sering merasa tidak enak hati untuk mengatakan "tidak" atau menolak pendapat ataupun permintaan temannya, misalnya ketika ada salah satu teman yang mengajak klien untuk melakukan hal negatif, maka klien merasa sulit untuk menolaknya karena takut dengan anggapan teman-temannya. Berdasarkan pernyataan klien tersebut, teridentifikasi bahwa klien mempunyai permasalahan dengan pengontrolan emosi (aggressive) dan sulit untuk dapat mengekspresikan atau menyampaikan pemikirannya (non-assertive).

Tahapan kedua yang harus dilakukan kliena dalah merencanakan tindakan yang akan dilakukan selanjutnya dalam proses pendampingan yang dikenal dengan istilah Plan of Treatment (POT). Plan of Treatment harus dibuat sejalan atau berdasarkan hasil yang telah didapat dari proses assessment dan bertujuan untuk menetapkan langkah-langkah yang tepat. Plan of Treatment (POT) berisikan pencapaian tujuan dan sasaran dari hasil yang telah disepakati antara klien dengan pendamping. Ashman (1993) mengemukakan bahwa penyusunan Plan of Treatment (POT) bersifat sistematis, sehingga teridentifikasi permasalahan dan prioritas penyelesaiannya yang akan dilakukan. Dalam proses ini ditentukan bahwa sasaran dan tujuan yang akan dicapai adalah pengendalian emosi yang baik (dengan teknik deep breathing) dan penguatan karakter asertif pada diri klien dengan menggunakan teknik assertiveness training.

Tahapan selanjutnya setelah perencanaan adalah pelaksanaan treatment kepada klien. Tahapan treatment atau proses intervensi merupakan proses yang di dalamnya terdapat metode-metode ataupun teknik-teknik intervensi. Proses intervensi dalam praktik pekerjaan sosial merupakan aktivitas professional yang dapat dilakukan kepada pihak lain secara individu, kelompok maupun masyarakat. Seperti yang sudah direncanakan pada tahap Plan of Treatment (POT) bahwa akan ada dua teknik intervensi yang dilakukan yaitu intervensi dengan teknik deep 


\begin{tabular}{|c|c|c|c|c|}
\hline $\begin{array}{c}\text { Prosiding Penelitian \& } \\
\begin{array}{c}\text { Pengabdian Kepada } \\
\text { Masyarakat }\end{array}\end{array}$ & $\begin{array}{c}\text { e ISSN : 2581-1126 } \\
\text { p ISSN : 2442-448X }\end{array}$ & Vol 6, No: 3 & Hal: 297 - 306 & Desember 2019 \\
\hline
\end{tabular}

breathing dan teknik assertiveness training. Namun, proses pendampingan ini akan difokuskan kepada penggunaan teknik assertiveness training dalam usaha menciptakan perilaku asertif dalam diri klien.

Teknik assertiveness training pertama kali dilakukan dalam bentuk permainan kelompok dengan bentuk bermain peran atau role play. Langkah pertama yang dilakukan yaitu membagi 20 orang ANDIK menjadi beberapa kelompok yang terdiri dari tiga orang ANDIK untuk setiap kelompoknya yang di dampingi oleh dua orang fasilitator yang berasal dari para praktikan untuk memberikan informasi kepada para ANDIK mengenai hal-hal apa saja yang harus dilakukan dalam kegiatan berkelompok.

Kemudian setiap kelompok diberikan sebuah isu oleh para fasilitator tentang suatu kejadian sosial yang sering terjadi di masyarkat, lalu setiap kelompok harus memberikan respon mereka terhadap isu yang telah diberikan oleh fasilitator. Contoh isu yang diberikan yaitu bagaimana respon kalian (ANDIK) ketika ada seseorang yang merokok di dalam sarana transportasi umum seperti kereta? Bagaimana respon kalian (ANDIK) jika kalian sedang belajar namun ada teman yang mengajak bermain? Bagaimana respon kalian (ANDIK) jika ada seorang perempuan yang sedang dipukuli oleh seorang laki-laki? Bagaimana respon kalian (ANDIK) jika kalian sedang berada di dalam kamar (karena di LPKA satu kamar di isi oleh kurang lebih 10 orang) lalu ada seseorang yang sangat berisik?

Dalam role play tersebut walaupun tidak semua kelompok dapat menunjukan respon yang asertif, namun hampir setiap kelompok menunjukan contoh-contoh dari perilaku yang asertif meskipun pada saat dilakukan role play, para ANDIK belum diberikan pengetahuan mengenai assertiveness training.
Setelah role play selesai dilakukan, barulah diberikan apresiasi atas respon dari semua kelompok dan diberikan pengetahuan umum oleh praktikan bahwa respon yang diberikan oleh beberapa kelompok disebut sebagai perilaku asertif. Ketika salah seorang ANDIK diminta untuk menyampaikan pendapatnya mengenai kesan tentang kegiatan tersebut, ia menjawab bahwa role play tersebut memberikan informasi mengenai perilaku yang sopan dalam menyampaikan sesuatu kepada orang lain.

Setelah role play selesai dilakukan, selanjutnya dilakukan intervensi secara individu atau case work. Pada proses intervensi individu, klien diberikan pengetahuan yang lebih mendalam mengenai perilaku asertif, seperti terdapat tiga perilaku yang biasa dilakukan oleh manusia dalam rangka menerapkan teknik assertiveness training. Tiga perilaku tersebut yaitu non-assertive, assertive dan aggressive. Ketiga perilaku tersebut mempunyai ciri-ciri sebagai berikut (Taftazani, 2019):

Tabel 1

Ciri-Ciri Tiga Perilaku Dalam Teknik Assertiveness Training

\begin{tabular}{|c|c|c|}
\hline NON-ASSERTIVE (submissive) & AGGRESSIVE & ASSERTIVE \\
\hline $\begin{array}{ll}- & \text { Bicara pelan (nyaris tidak } \\
& \text { terdengar) } \\
\text { - } & \text { Pandangan menghindar } \\
\text { - } & \text { Menghindar masalah/isu }\end{array}$ & $\begin{array}{ll}- & \text { Memotong sebelum } \\
\text { orang lain menyelesaikan } \\
\text { pembicaraannya } \\
\text { - } \quad \text { berbicara dengan keras } \\
\text { dan kasar }\end{array}$ & $\begin{array}{ll}- & \text { menjawab secara } \\
\text { spontan, berbicara } \\
\text { dengan tekanan dan } \\
\text { volume suara percakapan } \\
\text { - } \quad \text { melihat / menatap lawan } \\
\text { bicara }\end{array}$ \\
\hline
\end{tabular}




\begin{tabular}{|c|c|c|c|c|}
\hline $\begin{array}{c}\text { Prosiding Penelitian \& } \\
\begin{array}{c}\text { Pengabdian Kepada } \\
\text { Masyarakat }\end{array}\end{array}$ & $\begin{array}{c}\text { e ISSN : 2581-1126 } \\
\text { p ISSN : 2442-448X }\end{array}$ & Vol 6, No: 3 & Hal: 297 - 306 & Desember 2019 \\
\hline
\end{tabular}

\begin{tabular}{|c|c|c|}
\hline $\begin{array}{ll}\text { - } & \text { Menyetujui dengan tidak } \\
\text { memeperdulikan } \\
\text { perasaan sendiri } \\
\text { - } \quad \text { Memberikan pendapat } \\
\text { dengan tidak jelas/tegas } \\
\text { - } \quad \text { Menilai diri sendiri lebih } \\
\text { rendah dari yang lain } \\
\text { - } \quad \text { Menyakiti diri sendiri } \\
\text { untuk menghindari } \\
\text { kemungkinan menyakiti } \\
\text { roang lain }\end{array}$ & $\begin{array}{ll}\text { - } & \text { pandangan menyorot / } \\
\text { - } & \text { melotot } \\
\text { berbicara melampaui isu } & \text { yang dibahas } \\
\text { (menyalahkan / } \\
\text { merendahkan) } \\
\text { - } \quad \text { menjelaskan pendapat } \\
\text { dan apa yang dirasakan } \\
\text { dengan berapi-api } \\
\text { - } \quad \text { menilai orang lain lebih } \\
\text { rendah dari diri kita } \\
\text { sendiri } \\
\text { - menyakiti orang lain } \\
\text { untuk menghindari } \\
\text { tersakitinya diri sendiri }\end{array}$ & $\begin{array}{ll}\text { - } & \text { berbicara pada isu } \\
\text { - } & \text { secara terbuka } \\
\text { mengungkapkan pendapt } \\
\text { dana pa yang dirasakan } \\
\text { (marah, cinta } \\
\text { ketidaksetujuan dan } \\
\text { kesedihan) } \\
\text { - } \quad \text { menilai diri sendiri setara } \\
\text { dengan orang lain } \\
\text { - menghindari untuk tidak } \\
\text { menyakiti diri sendiri } \\
\text { maupun orang lain }\end{array}$ \\
\hline
\end{tabular}

Sumber: Taftazani, 2019

Teknik assertiveness training dilakukan agar klien mengetahui bagaimana cara merespon segala kejadian yang ia hadapi dengan tepat menggunakan perilaku asertif. Proses intervensi individu juga dilakukan dengan pemberian langsung contoh kejadian yang dihadapi klien dan tindakan apa yang akan dilakukan klien secara spontan kemudian selanjutnya dilakukan perbaikan terhadap perilaku yang seharusnya diambil dengan melihat pada ciri-ciri perilaku asertif.

Setelah proses treatment dilakukan, maka ada dua tahap lagi yang harus dilakukan, yaitu tahap evaluasi dan terminasi. Proses evaluasi dilakukan dengan menanyakan kepada klien beberapa pertanyaan berikut ini:

1. Apa manfaat yang dirasakan klien setelah pemberian teknik assertiveness training?

Klien menjawab bahwa setelah mendapat pengetahuan tersebut, ia dapat belajar bahwa dalam kehidupan sehari-hari klien harus bertindak dengan sopan dan baik karena jika ia bertindak agresif, maka perilaku tersebut dapat membuat orang lain menjadi emosi dan menyebabkan keributan. Klien pun menyatakan bahwa dirinya tidak mau lagi bertindak nonassertive jika ada teman yang mengajak melakukan hal-hal yang negatif. Bila hal tersebut terjadi lagi, klien akan dengan tegas menolak ajakan tersebut. Klien merasa bahwa perilaku asertif akan bermanfaat ketika ia sudah selesai menjalani proses pembinaan di LPKA dan di perbolehkan untuk kembali ke rumah.

2. Bagaimana intensitas penerapan perilaku asertif dalam kehidupan sehari-hari klien? Apa contoh perilaku asertif yang telah klien lakukan?
Klien menjawab bahwa setelah proses treatment, ia sering menerapkan perilaku asertif dalam kehidupan sehari-hari. Klien menceritakan penerapan dari perilaku asertif yang ia lakukan contohnya ketika ada seorang teman ANDIK yang mengajak klien untuk membatalkan puasa (karena proses intervensi dilakukan ketika bulan Ramadhan), maka klien berusaha menolaknya dengan tegas namun tetap menghormati orang tersebut yaitu dengan mengatakan tidak karena sebentar lagi maghrib, lalu kemudian ia memilih untuk tidur daripada terpengaruh untuk membatalkan puasa. Contoh kedua yang diceritakan oleh klien adalah ketika klien diajak untuk tidak melaksanakan sholat oleh salah satu temannya. Respon yang diberikan klien adalah menolak dengan halus dan mengatakan tidak, kemudian klien melakukan sholat terlebih dahulu.

\section{SIMPULAN DAN SARAN}

Pada kegiatan praktikum ini, praktikan dapat mengetahui bahwa masa remaja sangat rentan dengan pengaruh negatif terutama dari lingkungan sekitar seperti lingkungan pertemanan (peer group). Selain faktor pengawasan oleh keluarga, yang dapat dilakukan sebagai upaya pencegahan terjadinya kenakalan remaja adalah melakukan penguatan karakter pada diri remaja sebagai upaya yang sangat penting untuk dilakukan.

Pentingnya menerapkan perilaku asertif sejak dini menjadi hal yang harus diperhatikan dan ditanamkan dalam diri setiap individu. Hal ini dianggap penting agar setiap individu dapat mengekspresikan diri dengan baik namun tetap 


\begin{tabular}{|c|c|c|c|c|}
\hline $\begin{array}{c}\text { Prosiding Penelitian \& } \\
\begin{array}{c}\text { Pengabdian Kepada } \\
\text { Masyarakat }\end{array}\end{array}$ & $\begin{array}{c}\text { e ISSN : 2581-1126 } \\
\text { p ISSN : 2442-448X }\end{array}$ & Vol 6, No: 3 & Hal: 297 - 306 & Desember 2019 \\
\hline
\end{tabular}

menghormati hak asasi yang dimiliki setiap individu.

Assertiveness training dapat menjadi salah satu metode intervensi yang tepat untuk memberikan pengetahuan kepada setiap individu termasuk para Anak Berhadapan dengan Hukum $(\mathrm{ABH})$ di Lembaga Pembinaan Khusus Anak (LPKA) mengenai perilaku asertif. Melihat besarnya manfaat yang akan diperoleh dengan pemahaman perilaku asertif pada diri seorang remaja, maka sudah seharusnya pemerintah Indonesia mempertimbangkan untuk menyisipkan pemberian materi tentang perilaku asertif dalam program pendidikan formal ataupun non formal bagi para remaja sebagai generasi penerus bangsa Indonesia.

\section{UCAPAN TERIMA KASIH}

Ucapan terima kasih ini ditujukan kepada semua pihak yang telah memberikan bantuan, bimbingan, dukungan, serta semangat kepada saya selama melakukan proses praktikum hingga penulisan artikel ini.

Dengan segala kerendahan hati, saya menyampaikan terima kasih sebesar-besarnya kepada yang terhormat:

1. Kantor Wilayah Kementerian Hukum dan HAM Kota Bandung yang telah memberikan izin Praktikum di Lembaga Pembinaan Khusus Anak (LPKA).

2. Lembaga Pembinaan Khusus Anak Bandung (LPKA) Kota Bandung.

3. Pihak supervisor Lembaga Pembinaan Khusus Anak Bandung.

4. Para dosen pengampu mata kuliah praktikum pekerjaan sosial dengan individu dan pengembangan diri.

5. Para ANDIK yang menjadi klien praktikum di LPKA.

6. Teman-teman praktikum LPKA.

7. Serta semua pihak yang tidak dapat disebutkan satu persatu.

\section{DAFTAR PUSTAKA}

Assertiveness Tarining. (n.d.). Retrieved from http://www.abct.org/docs/factsheets/AS SERTIVENESS.pdf

Fuziah, A. (2015). Perubahan Perilaku Sosial Remaja Pasca Perceraian Orang Tua. Retrieved from http://digilib.uinsby.ac.id/2164/
Hurlock, E.B. (1990). Developmental Psychology: A Lifepan Approach. (Terjemahan oleh Istiwidayanti). Jakarta: Erlangga Gunarsa.

Herlina. (2013). Bibliotherapy: Mengatasi Masalah Anak dan Remaja melalui Buku. Bandung: Pustaka Cendikia Utama.

Jatnika, D. C., Raharjo, S. T., \& Mulyana, N. (2016). Pekerjaan Sosial Koreksional Kasus Integrasi Anak Didik LPKA Ke Masyarakat.

Kartika, N. (n.d.). Memahami Kasus Anak dengan Hukum melalui Teori ProblemBehavior. Kompasiana. Retrieved August 7, 2018, from https://www.kompasiana.com/novia120 304/5b69c69ed1962e2abf124d74/mema hami-kasus-anak-anak-yangberhadapan-dengan-hukum-melaluiperspektif-teori-problembehavior?page $=$ all

Krori, Smita Deb. (2011). Developmental Psychology, dalam Homeopathic Journal Volume: 4, Issue: 3, Jan, 2011. Retrieved: http://www.homeorizon.com/ homeopathicarticles/psychology/developmentalpsychology.

M. (2017). Efektivitas Layanan Konseling Kelompok Teknik Assertive Training Dalam Meningkatkan Disiplin Belajar Peserta Didik Kelas X SMA Negeri 14 Bandar Lampung. Retrieved from http://repository.radenintan.ac.id/1653/ 1/Skripsi_Full_Musdariah.pdf

Muwanah, L. B., \& Pratikto, H. (2012). Kematangan Emosi, Konsep Diri Dan Kenakalan Remaja. Retrieved from https://media.neliti.com/media/publicati ons/127014-ID-kematangan-emosikonsep-diri-dan-kenakal.pdf.

N. (2015). Teknik Assertive Training (At) Untuk Meningkatkan Perilaku Asertif Siswa. Retrieved from https://ejournal.stkipmpringsewuIpg.ac.id/index.php/fokus/article/view/7 $1 / 157$.

Oktarosada, D. (2017). Implementasi Pendidikan Karakter Pada Pembelajaran Pendidikan Agama Islam Di Kelas X: Studi Kasus Di SMK Muhammadiyah 2 Kalirejo. Retrieved from http://repository.radenintan.ac.id/2236/ 


\begin{tabular}{|c|c|c|c|c|}
\hline $\begin{array}{c}\text { Prosiding Penelitian \& } \\
\begin{array}{c}\text { Pengabdian Kepada } \\
\text { Masyarakat }\end{array}\end{array}$ & $\begin{array}{c}\text { e ISSN : 2581-1126 } \\
\text { p ISSN : 2442-448X }\end{array}$ & Vol 6, No: 3 & Hal: 297 - 306 & Desember 2019 \\
\hline
\end{tabular}

Praktikum Makro (Pengembangan Masyarakat).
(2011)
Retrieved
from
http://kesos.unpad.ac.id/wp-
content/uploads/2012/07/Buku-
Pedoman-Pelaksanaan-Praktikum-
Makro-2011.pdf

Putro, K. Z. (2017). Memahami Ciri dan Tugas Perkembangan Masa Remaja. Retrieved from http://ejournal.uinsuka.ac.id/pusat/aplikasia/article/viewFil e/1362/1180

Raharjo, S. T. (2016). Dasar Pengetahuan Pekerjaan Sosial. https://studylibid.com/doc/1045142/das ar-pengetahuan-pekerj

Richard, T. (2018, March 27). Menengok Lembaga Pembinaan Khusus Anak Bandung, Tetap Sekolah dan Pintu Tak Digembok. TribunJabar. Retrieved from https://jabar.tribunnews.com/2018/03/2 7/menengok-lembaga-pembinaankhusus-anak-bandung-tetap-sekolahdan-pintu-tak-digembok?page=all

Santoso, M. B. (2017). Remaja Berisiko. Sumedang: Niaga Muda Press.

Sarwono, S.W. (2001). Psikologi Remaja. Jakarta: Rajawali Pers.

Sarwono, S. (2011). Psikologi Remaja. Jakarta: PT. Rajagrafindo Persada.

Taftazani, B. M. (2019). Assertiveness Training. Presentasi Perkuliahan (tidak dipublikasikan).

Y., \& Ernis, Y. (2016). Lembaga Pembinaan Khusus Anak Dalam Perspektif Sistem Peradilan Pidana Anak. Retrieved from http://sipkumham.balitbangham.go.id/a ssets/img/dokumenpenelitian/PTL20171 109015102016_A20.pdf

Yusuf, S. (2005). Psikologi Perkembangan Anak dan Remaja. Bandung: PT Remaja Rosdakarya.

Z. (2017). Relevansi Teknik Assertive Training Dalam Konseling Dengan Beberapa Hadits Rasulullah Saw. Retrieved from https://repository.arraniry.ac.id/1008/1/Zikriani.pdf 